\title{
Spatially explicit fate factors of waterborne nitrogen emissions at the global scale
}

\author{
Cosme, Nuno Miguel Dias; Mayorga, Emilio; Hauschild, Michael Zwicky
}

Published in:

International Journal of Life Cycle Assessment

Link to article, DOI:

10.1007/s11367-017-1349-0

Publication date:

2018

Document Version

Peer reviewed version

Link back to DTU Orbit

Citation $(A P A)$ :

Cosme, N. M. D., Mayorga, E., \& Hauschild, M. Z. (2018). Spatially explicit fate factors of waterborne nitrogen emissions at the global scale. International Journal of Life Cycle Assessment, 23(6), 1286-1296.

https://doi.org/10.1007/s11367-017-1349-0

\section{General rights}

Copyright and moral rights for the publications made accessible in the public portal are retained by the authors and/or other copyright owners and it is a condition of accessing publications that users recognise and abide by the legal requirements associated with these rights.

- Users may download and print one copy of any publication from the public portal for the purpose of private study or research.

- You may not further distribute the material or use it for any profit-making activity or commercial gain

- You may freely distribute the URL identifying the publication in the public portal 


\title{
Spatially explicit fate factors of waterborne nitrogen emissions at the global scale
}

\author{
Nuno Cosme ${ }^{\text {a }}$, Emilio Mayorga ${ }^{\text {b }}$, Michael Z. Hauschild ${ }^{\text {a }}$ \\ ${ }^{a}$ Division for Quantitative Sustainability Assessment, Department of Management Engineering, Technical University \\ of Denmark, Bygningstorvet 116B, 2800 Kongens Lyngby, Denmark \\ b Applied Physics Laboratory, University of Washington, 1013 NE 40 ${ }^{\text {th }}$ St., Seattle, WA 98105-6698, USA \\ Corresponding author: Nuno Cosme,nmdc@dtu.dk; nmcosme@gmail.com
}

\begin{abstract}
Purpose

Marine eutrophication impacts due to waterborne nitrogen $(\mathrm{N})$ emissions may vary significantly with their type and location. The environmental fate of dissolved inorganic nitrogen (DIN) forms is essential to understand the impacts they may trigger in receiving coastal waters. Current life cycle impact assessment (LCIA) methods apply fate factors (FFs) with limited specificity of DIN emission routes, and often lack spatial differentiation and global applicability. This paper describes a newly developed method to estimate spatially explicit FFs for marine eutrophication at a global scale and river basin resolution.

Methods
\end{abstract}

The FFs modelling work includes DIN removal processes in both inland (soil and river) and marine compartments. Model input parameters are the removal coefficients extracted from the Global NEWS 2-DIN model and residence time of receiving coastal waters. The resulting FFs express the persistence of the fraction of the original DIN emission in the receiving coastal large marine ecosystems (LMEs). The method further discriminates three DIN emission routes, i.e. diffuse emission from soils, and direct point emissions to fresh- or marine waters. Based on modelling of individual river basins, regionally aggregated FFs are calculated as emission-weighted averages.

Results and discussion

Among 5772 river basins of the world, the calculated FFs show 5 orders of magnitude variation for the soil-related emission route, 3 for the river-related, and 2 for emissions to marine water. Spatial aggregation of the FFs at the continental level decreases this variation to 1 order of magnitude or less for all routes. Coastal water residence time was found to show inconsistency and scarcity of literature sources. Improvement of data quality for this parameter is suggested. 


\section{Conclusions}

With the proposed method and factors, spatial information of DIN emissions can be used to improve the environmental relevance and the discriminatory power of the assessment of marine eutrophication impacts in a geographically differentiated characterization model at a global scale.

Keywords Watershed · River basin · Coastal water · Large Marine Ecosystems · Denitrification · Removal processes · Residence time $\cdot$ Life cycle impact assessment

\section{Table of Contents}

Abstract

1 Introduction

2 Methods

2.1 Framework

2.1.1 Nitrogen sources and emissions

2.1.2 Life cycle impact assessment

2.2 Model structure

2.2.1 Inland fate component

2.2.2 Marine fate component

2.3 Regional aggregation

3 Results and discussion

3.1 Fate factors

3.2 Spatial differentiation

3.3 Qualitative comparison with other models

\section{Introduction}

Marine coastal eutrophication can be defined as the syndrome of ecosystem responses to the increase in supply of growth-limiting plant nutrients that boost planktonic growth and fuel organic carbon cycling processes (Nixon 1995; Cloern 2001). Nitrogen (N) is assumed to be the limiting nutrient in marine waters - a common simplification in ecosystems modelling, considering average spatial and temporal representative conditions (see also Vitousek et al. 2002; Howarth and Marino 2006; Cosme et al. 2015), although point limitations by phosphorus or silica (Turner et al. 1998; Elser et al. 2007) and cases of co-limitation (Arrigo 2005) may occur.

The cascading effects of $\mathrm{N}$ enrichment in the marine ecosystem include increased plant biomass, algal blooms, shading, water quality degradation, loss of habitat, and oxygen deficiency (NRC 2000; Rabalais 2002; Kelly 2008). 
These can lead to important ecological impacts that range from altered ecological communities and species composition, and reduced abundance and diversity of biological resources, to mass mortality (Diaz and Rosenberg 1995; Wu 2002; Levin et al. 2009; Middelburg and Levin 2009; Zhang et al. 2010). The onset of hypoxic conditions and 'dead zones', due to excessive oxygen depletion by aerobic respiration of organic matter, has already been noted as one of the most severe and widespread causes of disturbance to marine ecosystems (GESAMP 2001; Diaz and Rosenberg 2008). Although hypoxia-driven eutrophication may occur naturally, it has been linked to increasing anthropogenic pressure (Smith et al. 1999, 2006; Gray et al. 2002; Rabalais 2002; Doney 2010; Howarth et al. 2011). Marine eutrophication is of global concern and likely to increase due to the growing population and urbanization, and the dependency on crops using fertilizers that results in resource intensification and emissions (Rabalais et al. 2010). Galloway et al. $(2004,2008)$ estimated a >10-fold increase of reactive nitrogen creation in the last 150 years and current $\mathrm{N}$ mobilization more than doubles that of natural processes, while riverine export has increased 5-6 fold since the preindustrial period (Galloway and Cowling 2002; Green et al. 2004).

In the cascade of effects caused by the $\mathrm{N}$ enrichment, those on coastal waters are typically modelled, in life cycle impact assessment (LCIA) methods, at the midpoint between $\mathrm{N}$ emissions and damage to ecosystems. Current LCIA methods do not account for impacts at the damage (or endpoint) level due to the lack of a consistent link from the $\mathrm{N}$ emissions (Hauschild et al. 2013; Henderson 2015). Generically, in this LCIA phase of the life cycle assessment (LCA) framework, inventoried emissions of substances are converted into potential impacts on the chosen indicator for the impact category by applying characterization factors (CFs). These, combine the environmental fate of the emitted substances, and the exposure and effects in relevant environmental compartments (Pennington et al. 2004). In this framework, fate factors (FFs) represent the persistence of a substance in the environment by quantifying its removal in the pathway from source to receiving compartment. In the present case, causes for $\mathrm{N}$ removal may include denitrification, advection, and abstraction by water consumption (Howarth et al. 1996; Seitzinger et al. 2005, 2006). The impact assessment further includes exposure (XF) and effect factors (EF). In the case of hypoxia-driven eutrophication, XF may correspond to the conversion of $\mathrm{N}$ uptake by primary producers into benthic oxygen consumption, as modelled in Cosme et al. (2015) for LCIA application. Similarly, EF may correspond to the sensitivity of ecological communities to hypoxia, as modelled in Cosme and Hauschild (2016).

Several LCIA methods have incorporated spatial differentiation when modelling FFs for nutrient emissions. The fate model CARMEN (Beusen 2005), with the EUTREND model (Van Jaarsveld 1995), is used at the European scale and country resolution in the EDIP2003 (Hauschild and Potting 2005) and ReCiPe (Goedkoop et al. 2012) impact 
methods, and also in a modified version for Canada in the LUCAS method (Toffoletto et al. 2007); hydrological model work by Vörösmarty et al. (2000a) and Fekete et al. (2000) at U.S. state scale is applied in TRACI method (Bare et al. 2003). However, a spatially explicit method consistently describing the fate of waterborne $\mathrm{N}$ emissions for application at the global scale is not available.

Spatial differentiation has been demonstrated to be an important feature in impact assessment. It increases both the environmental relevance and discriminatory power of the underlying models (Udo de Haes et al. 2002; Potting and Hauschild 2006), especially for impacts occurring at the local to regional scale, such as marine eutrophication. Coarse spatial resolution and incompatibility of model results for different regions may hinder harmonisation of LCIA methods and reduce the relevance and applicability of the studies. Ensuring both an adequate spatial resolution, in view of the spatial variability of the impacts, and a global coverage of the FF model, would contribute to improve the state-of-theart of marine eutrophication impact assessment.

The goal of the present study is to develop a global method for spatial differentiation in fate modelling for waterborne nitrogen emissions and apply it to derive spatially explicit fate factors to be used in the assessment of marine eutrophication impacts at a global scale. For this purpose, the N removal processes used in the Global NEWS 2DIN model (Seitzinger et al. 2005; Mayorga et al. 2010) were coupled with those acting in the marine compartment. The driving environmental fate processes were identified and analysed, and important assumptions and uncertainties discussed.

\section{Methods}

\section{$2.1 \quad$ Framework}

\subsubsection{Nitrogen sources and emissions}

Fertilizers (both inorganic and organic) applied in agriculture result in waterborne $\mathrm{N}$ emissions to the environment, mainly in the form of dissolved $\mathrm{NH}_{4}{ }^{+}$and $\mathrm{NO}_{3}{ }^{-}$from soil to water (Galloway et al., 2002; Socolow, 1999). Biological nitrogen fixation, i.e. the fixation of atmospheric $\mathrm{N}_{2}$ to (mainly) $\mathrm{NH}_{4}{ }^{+}$, contributes with an additional input to the soil budget (Galloway et al. 2004). The $\mathrm{N}$ input may then be reduced by crop removal (by harvesting and grazing), ammonia volatilization, and denitrification in the soil. Discounting any soil storage of $\mathrm{N}$, the remainder constitutes the soil budget $\mathrm{N}$ surplus, which represents the environmental emission. Subsequently, it is leached from the root zone, and further reduced by denitrification in groundwater systems and retention in river systems (Bouwman et al. 2005). As such, emitted $\mathrm{N}$ forms enter the aquatic system by surface runoff and leaching from soils to rivers, by direct emissions to 
rivers or to marine coastal waters, or by atmospheric deposition. Although the contributions from the latter (airborne emissions) are not modelled here, the fate of any quantified deposition of nitrogen oxides $\left(\mathrm{NO}_{\mathrm{x}}\right)$ or ammonia $\left(\mathrm{NH}_{3}\right)$ on soil, river or coastal water can be calculated with the FF for the respective emission route, independently of the source. Sources of waterborne $\mathrm{N}$ inputs are typically categorized as point or non-point, mainly for management purposes, depending on the nature of the emission - if it occurs at specific emission locations (e.g. sewage water discharges) or is diffused in the landscape (e.g. runoff from agricultural soils), respectively.

\subsubsection{Life cycle impact assessment}

The method presented here supports the calculation of FFs for waterborne $\mathrm{N}$ emissions from anthropogenic sources as part of the characterization of their ability to contribute to eutrophying effects in marine coastal waters. The underlying modelling work is consistent with the LCIA framework for emission-related impact indicators (Udo de Haes et al. 2002) by describing the environmental fate processes of $\mathrm{N}$ in soil and riverine systems, aggregated at river basin scale (Vörösmarty et al. 2000b), and in the coastal marine compartment, at large marine ecosystem (LME) scale (Sherman and Alexander 1986). Additional modelling of (i) ecosystem responses to exposure to $\mathrm{N}$ and oxygen depletion resulting from organic carbon cycling processes, and (ii) effects based on sensitivity of marine species to hypoxia, is needed to complete the characterization model for hypoxia-driven marine eutrophication impacts. The modelling of these elements, i.e. the exposure and the effects, are described in Cosme et al. (2015) and Cosme and Hauschild (2016), respectively. The combination of the fate, exposure, and effect models composes the characterization model for which the characterization factor $\left(\mathrm{CF},\left[\mathrm{m}^{3} \cdot \mathrm{yr} \cdot \mathrm{kgN}^{-1}\right]\right)$ is calculated as summarised in Eq. (1) (Cosme and Hauschild 2017):

$C F_{i, j l}=F F_{i, j l} \times X F_{l} \times E F_{l}$

where $\mathrm{FF}_{i, j l}[\mathrm{yr}]$ is the fate factor for emission route $i$ in river basin $j$ to receiving ecosystem $l, \mathrm{XF}_{l}\left[\mathrm{kgO}_{2} \cdot \mathrm{kgN}^{-1}\right]$ the exposure factor and $\mathrm{EF}_{l}\left[\mathrm{~m}^{3} \cdot \mathrm{kgO}_{2}^{-1}\right]$ the effect factor in ecosystem $l$. As each river basin exports to a single $\mathrm{LME}, j l$ are coupled in the subscript of CF and FF notations. The method described and discussed here is limited to the derivation of FFs at a river basin scale with global coverage applicable to emissions of dissolved inorganic nitrogen (DIN) forms.

\subsection{Model structure}

Fate factors express the resident mass [ $\mathrm{kg}]$ per unit of emission $\left[\mathrm{kg} \mathrm{yr}^{-1}\right]$, yielding an overall dimension of [yr]. As such, the FF in Eq. (1) describes the persistence of the fraction of the original DIN emission in the receiving ecosystem. The 
fate model is composed of an inland and a marine fate component. The inland component describes the removal processes in soil and rivers that determine the fraction exported to coastal waters $\left(f_{\mathrm{N}}\right.$, [dimensionless]). The marine component describes the fate processes occurring in the marine compartment that ultimately determine the persistence of DIN there, equivalent to the inverse of the sum of the removal rates $\left(\lambda,\left[\mathrm{yr}^{-1}\right]\right)$. In the case of $\mathrm{N}$ emitted, the output of the inland fate component is the input to the marine component, the fate factor $\left(\mathrm{FF}_{i, j l},[\mathrm{yr}]\right)$ is calculated by combining the inland fate and marine fate components, for each emission route $i$ in river basin $j$ to receiving ecosystem $l$, as presented in Eq. (2).

$F F_{i, j l}=\frac{f_{N_{i, j}}}{\lambda_{l}}$

The emission routes are defined as 'DIN from soil' $\left(\mathrm{N}_{\text {soil }}\right)$ and direct emission to river as 'DIN to river' $\left(\mathrm{N}_{\text {riv }}\right)$ or to coastal waters as 'DIN to marine water' $\left(\mathrm{N}_{\mathrm{mar}}\right)$, as used in Table 1 Table 3 and Fig. 1 . DIN forms include nitrate $\left(\mathrm{NO}_{3}{ }^{-}\right.$ ), nitrite $\left(\mathrm{NO}_{2}^{-}\right)$, and ammonium $\left(\mathrm{NH}_{4}^{+}\right)$. The term DIN is generically used throughout the text referring to any of these forms.

\subsubsection{Inland fate component}

The DIN content of the emission is reduced by retention (and subsequent metabolic processing, biogeochemical transformation and physical retention) in the soil and water systems and additional losses (consumptive water removal) within the river system. This inland component estimation is based on the removal processes covered in the second generation of the Global Nutrient Export from WaterSheds suite of models (NEWS 2) (Dumont et al. 2005; Seitzinger et al. 2005, 2010; Mayorga et al. 2010). The NEWS 2 model estimates global and spatially explicit nutrient riverine exports covering N, P, C, and Si, their dissolved inorganic forms (DIN, DIP, DSi), dissolved organic forms (DON, DOP, DOC), and particulate N, P and C forms (PN, PP, POC) (Mayorga et al. 2010). The model relates natural and anthropogenic nutrient emission sources and natural transformation processes in watersheds to their export to receiving coastal waters, basing its spatial differentiation on a geographic information system (GIS). Its sub-model describing the riverine DIN export (NEWS 2-DIN) contains parameterisation data essential to understanding inland $\mathrm{N}$ losses (in natural and agricultural soils and riverine systems) and deriving fate-related coefficients.

The NEWS 2-DIN sub-model predicts the annual DIN export at river mouth for 6,272 river basins by combining both point and diffused $\mathrm{N}$ emissions with hydrologic, biogeochemical, climatic, and social variables (integrating various 
model work by Van Drecht et al. 2003, 2009; Green et al. 2004; Beusen et al. 2005; Bouwman et al. 2005, 2009; Dumont et al. 2005; Seitzinger et al. 2005; Dentener et al. 2006; Mayorga et al. 2010), using modelled runoff (Fekete et al. 2000) applied on the STN-30p river system and basin delineation (Vörösmarty et al. 2000b), on a global spatially explicit $0.5^{\circ}$ latitude $\times 0.5^{\circ}$ longitude grid.

The export fractions (FE) of DIN ( $F E_{D I N}$, dimensionless, as per NEWS models nomenclature), used to derive the inland fate component shown in Table 1, are determined in NEWS 2-DIN by:

- calibrated runoff functions from diffuse anthropogenic sources (agricultural soils) in the watersheds to rivers $\left(F E_{w s, a n t, D I N}\right)$ and from natural soils to rivers $\left(F E_{w s, n a t, D I N}\right)$, from which a river source-weighted average is calculated to deliver the export fraction from soil to river per watershed $\left(F E_{w s, D I N}\right)$ expressing the retention within soils, groundwater and riparian areas during transport to streams (treated as a permanent land sink) (Mayorga et al. 2010);

- riverine losses by denitrification (due to retention within reservoirs and along the river network) and consumptive water use (anthropogenic removal of river water containing DIN) $\left(F E_{r i v, D I N}\right)$.

In NEWS 2-DIN, each of these fractions apply to specific discrete $\mathrm{N}$ flows distinguished into river and watershed sources (in $\left.\left[\mathrm{kgN} \cdot \mathrm{km}^{-2} \cdot \mathrm{yr}^{-1}\right]\right)$, which are of either point ( $\left.p n t\right)$ or diffuse (dif) type and of anthropogenic (ant) or natural (nat) origin, to estimate the total river basin DIN yield (in $\left[\mathrm{kgN} \cdot \mathrm{km}^{-2} \cdot \mathrm{yr}^{-1}\right]$ ) (Mayorga et al. 2010). However, for the present model, the various $F E$ coefficients were identified and only these were combined in order to determine the inland fate, per river basin and for each emission route (Table 1).

Table 1 Inland fate equations $-f \mathrm{~N}_{\text {soil }}, f \mathrm{~N}_{\text {riv }}, f \mathrm{~N}_{\text {mar }}$ in river $j$, as applied in Eq. (2), derived from the export fractions (FE, [dimensionless]) in watershed (ws) and river (riv)

\begin{tabular}{|c|c|c|}
\hline Emission route & Inland fate coefficient [-] & Derived equation for exported fraction [-] \\
\hline DIN from soil & $f \mathrm{~N}_{\mathrm{soil}, j}=$ & $\mathrm{FE}_{\mathrm{ws}, \mathrm{DIN}, j} \times \mathrm{FE}_{\mathrm{riv}, \mathrm{DIN}, j}$ \\
\hline DIN to river & $f \mathrm{~N}_{\text {riv }, j}=$ & $\mathrm{FE}_{\text {riv, DIN }, j}$ \\
\hline DIN to marine water & $f \mathrm{~N}_{\mathrm{mar}, j}=$ & 1 (no inland fate component) \\
\hline
\end{tabular}

The DIN fractions exported from each exorheic river basin were linked to a receiving LME by means of the geographic location of the respective river mouth. This correspondence key was identified for 5772 discharging systems, after excluding 164 endorheic basins and 145 systems discharging to coasts outside the 66 LMEs coverage. Basin discharge information was not available for receiving ecosystems \#61 (Antarctic), \#64 (Central Arctic Ocean), and \#65 (Aleutian Islands). 
For guidance on application, and when emissions are not reported as dissolved inorganic $\mathrm{N}$ (e.g. total N), a conversion based on molar mass may be needed to determine $\mathrm{N}$ mass in the DIN form: for $\mathrm{N}_{\text {in }} \mathrm{NH}_{4}{ }^{+}$multiply by 0.776 , $\mathrm{N}$ in $\mathrm{NO}_{3}{ }^{-}$by $0.226, \mathrm{~N}$ in $\mathrm{NO}_{2}{ }^{-}$by 0.304 . For emissions of dissolved organic $\mathrm{N}$ (DON) to river, the organic load may be assumed to fully mineralise to DIN and the respective FF $_{\text {Nriv }}$ be applied, as a simplification. However, fate modelling of dissolved organic or particulate $\mathrm{N}$ forms, not described here, should adopt specific removal coefficients from the respective NEWS 2 sub-models, i.e. NEWS 2-DON or -PN.

For specific use, the $\mathrm{FF}_{\mathrm{Nsoil}}$ applies to inventoried diffuse emissions from agricultural and natural soils $\left(\mathrm{N}_{\text {soil }}\right)$ to rivers, whereas point (direct) emissions to rivers and marine coastal waters are to be covered by $\mathrm{N}_{\text {riv }}$ and $\mathrm{N}_{\mathrm{mar}}$, respectively. Direct emissions include sewage water discharge and effluents from wastewater treatment; DIN content of these emissions is needed for further impact estimation. An example of an application to a direct emission inventory flow and further development of the NEWS 2 export coefficients can be found in Strokal et al. (2016) for high-nutrient load discharges of animal manure, or to diffuse emissions from cropland in Huang et al. (2017).

\subsubsection{Marine fate component}

In the coastal zone, DIN is removed by advection and denitrification. Assuming that these removal processes are both first order (see also Seitzinger et al. 2006; Kroeze et al. 2012), the resulting marine removal rate $\left(\lambda\right.$, [yr $\left.\left.{ }^{-1}\right]\right)$ is estimated as the sum of the removal rates by advection $\left(\lambda_{\text {adv }}\right)$ and denitrification $\left(\lambda_{\text {denitr }}\right)$, in each receiving ecosystem $l$ (i.e. LME), Eq. (3).

$\lambda_{l}=\lambda_{a d v, l}+\lambda_{\text {denitr }, l}$

The advection removal coefficient $\left(\lambda_{\mathrm{adv}, \mathrm{l}},\left[\mathrm{yr}^{-1}\right]\right)$, Eq. (4), corresponds to the inverse of the surface water residence time $\left(\tau_{l},[\mathrm{yr}]\right)$ in ecosystem $l$.

$\lambda_{a d v, l}=\frac{1}{\tau_{l}}$

Adopting the residence time concept involves the assumption that the cumulative effect of all the water exchanges (inputs to and outputs from the LME) is reflected in this value. Therefore it is not necessary to quantify each individual source and sink to calculate the water persistence (and assumed DIN's as well) in the LME; rather, the 
residence time is used to estimate DIN removal from the euphotic water mass, i.e. by advection and denitrification. The use of $\tau_{l}$ to represent an advective transport removal, is described elsewhere for similar modelling work in lakes, estuaries, and coastal waters (e.g. Vollenweider 1976; Andrews and Müller 1983; Nixon et al. 1996; Dettmann 2001; Monsen et al. 2002; Seitzinger et al. 2006). Literature review provided residence times for 39 out of 66 LMEs. Two coastal archetypes were defined based on expert judgement of decisive aspects, like the coastal exposure to currents and regional ocean circulation (higher exposure and circulation tend to lead to faster water mass exchange), and continental shelf depth and profile (shallow and broad shelves tend to slow water mass exchange). The remaining 27 LMEs were classified into one of these archetypes and their $\tau_{l}$ estimated based on this classification. The archetypes were also used to settle cases where literature sources were inconsistent (Table S.1 in Electronic Supplementary Material). Archetypes were described as type 1 ( $\tau=0.25 \mathrm{yr}$ ) for short water persistence with high dynamics and exposure to regional currents, mainly above narrow and deep shelves, and type 2 ( $\tau=2 \mathrm{yr}$ ) with medium dynamics and exposure to local currents, mainly in broader and shallower shelves. The $\tau_{l}$ values adopted from the archetypes were compared with the literaturebased values for other LMEs with similar characteristics to check for consistency.

Denitrification is the microbially-mediated reduction of oxidized $\mathrm{N}$ forms $\left(\mathrm{NO}_{3}^{-}, \mathrm{NO}_{2}{ }^{-}\right.$and $\left.\mathrm{NO}\right)$ into biologically unavailable forms $\left(\mathrm{N}_{2}\right.$ and $\mathrm{N}_{2} \mathrm{O}$ ) (Seitzinger 1988; Socolow 1999). The nitrification-denitrification balance that ultimately may regulate $\mathrm{N}$ limitation (in low $\mathrm{N}$ availability systems) or reduce DIN export (in enriched systems) varies with geography and over time (Seitzinger et al. 2006). Taking a modelling approach with integration over time (annual) and space (LME), the effect of time and space may be represented through an empirical relationship, Eq. (5), between DIN removal (DIN $\mathrm{rem}, \%)$ as a function of water residence time (in months) in estuaries, river reaches, lakes, and continental shelf, as described by Seitzinger et al. (2006) extending work by Nixon et al. (1996).

$\operatorname{DIN}_{\text {rem }, k}=23.4 \cdot \tau_{l}^{0.204}$

The LME $(l)$-dependent denitrification rate constant $\left(\lambda_{\text {denitr }, l}\right)$ is determined from $\operatorname{DIN}_{\text {rem }}$ using a first-order removal equation, Eq. (6), with $t$ set to 1 year for the annual time integration represented in Eq. (5).

$D I N_{\text {rem }, l}=e^{-\lambda_{\text {denitr }, l} t} \Leftrightarrow \lambda_{\text {denitr }, l}=-\frac{\ln D I N_{\text {rem }, l}}{t}$ 
Although denitrification may be locally affected by temperature, supply of nitrate and organic matter, oxygen concentration, and also biotic parameters (Seitzinger 1988), it is a generic process independent of salinity (Fear et al. 2005; Magalhães et al. 2005). Therefore, the adoption of such empirical relationship is deemed representative of annual denitrification losses in marine coastal waters.

\subsection{Regional aggregation}

Combining the rate constants for denitrification and advection for an overall removal rate in the coastal ecosystems (Eq. (3)), and with the fraction removed in the inland compartment (Table 1), yields fate factors for 5772 discharging riverine systems. Considering the three emission routes, the number of possible FFs ascends to 17316 . If the exact emission location is known for a given emission, the corresponding FF can be applied in the calculation of the characterization factor. Often, such specific knowledge about emission location is not at hand for many processes in the life cycle. In order to support application in LCA, the fate factors have also been aggregated at higher geographic scales. Regional aggregation of FFs over any desired region (reg, e.g. continent, world) for each DIN emission route $i$, was calculated by DIN emission $(E m)$-weighted averages, as shown in Eq. (7). Regional fate factors $\left(\mathrm{FF}_{i, \text { reg }}\right.$, [yr]) aggregate all river basins with non-zero $\mathrm{FF}_{i, j l}$ belonging to region reg, with a corresponding DIN emission $E m$ in the respective route $i$. DIN emission data used refer to diffuse (from soils) and point (sewage) emissions in the year 2000 and were extracted from the NEWS 2-DIN model.

$F F_{i, r e g}=\frac{\sum_{r e g} F F_{i, r e g} \cdot E m_{i, r e g}}{\sum_{r e g} E m_{i, r e g}}$

\section{Results and discussion}

\subsection{Fate factors}

The FFs for waterborne $\mathrm{N}$ emissions are shown in Fig. 1 for the emission route 'DIN to river' $\left(\mathrm{N}_{\text {riv }}\right)$. Full results for the three emission routes in the 5772 river basins are available in the Electronic Supplementary Material. All three emission routes are equally affected by the marine fate component (represented in the $\mathrm{FF}_{\mathrm{Nmar}}$ ). This, can be seen as a baseline or tier 1 (Fig. S.1) and shows direct linear correlation with LME-dependent residence times $\left(\mathrm{FF}_{\mathrm{Nmar}} r=0.95\right)$. Removal processes in the river system $\left(\mathrm{FF}_{\mathrm{Nriv}}\right.$, Fig. 1) lie in a second tier, also dependent on residence time $\left(\mathrm{FF}_{\mathrm{Nriv}} r=0.87\right)$. In a 
third tier, fate is further modulated by specific losses, either in natural or agricultural soil, to express the respective FFs, less dependent on the residence time term $\left(\mathrm{FF}_{\mathrm{Nsoil}} r=0.45\right)$.

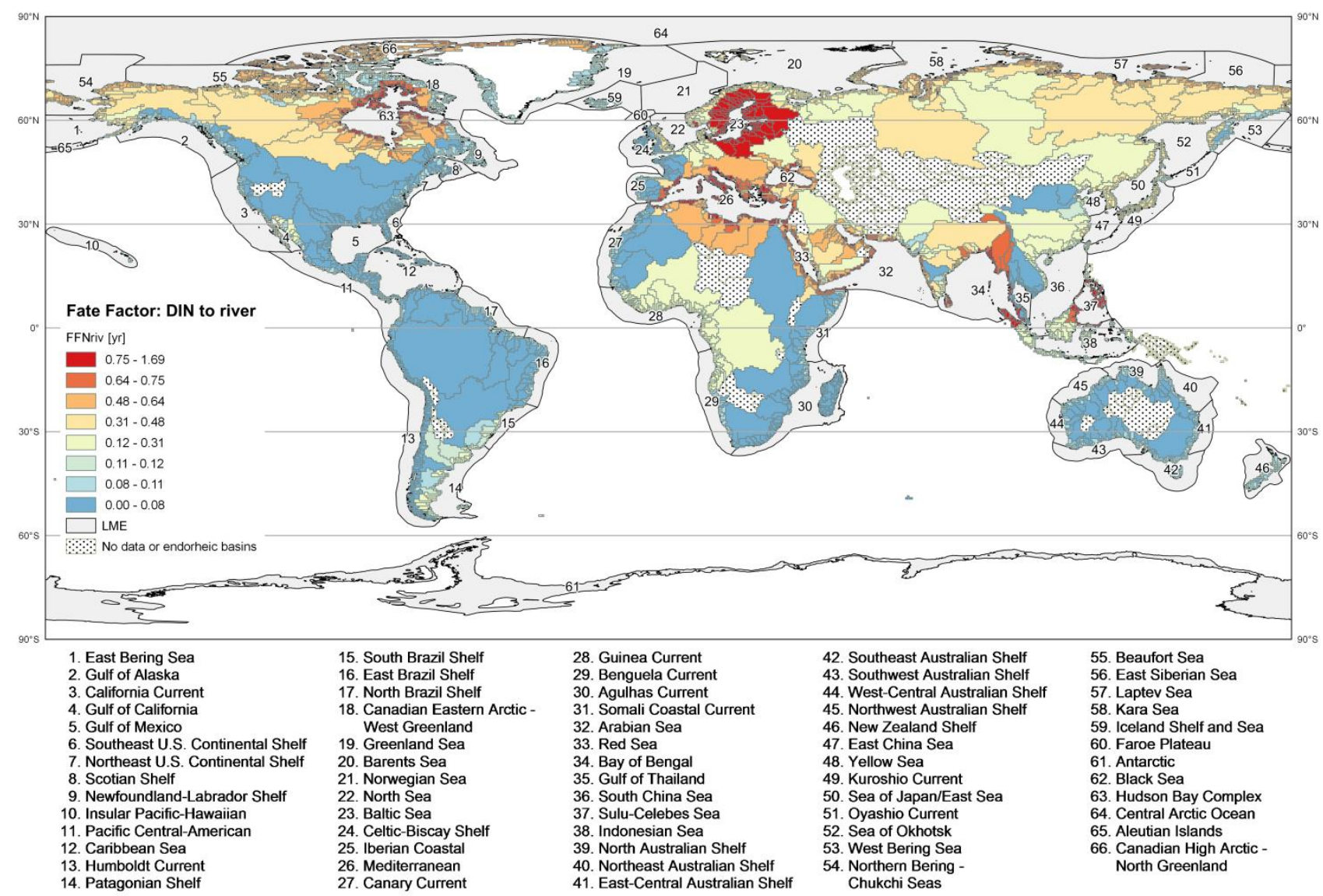

Fig. 1 Global distribution of the fate factors ( $\mathrm{FF}_{\mathrm{Nriv}}$, [yr]) for marine eutrophication for DIN emissions to river at a basin scale. Dotted areas correspond to basins that are endorheic, arid, or for other reason have no available FF. Note the non-linear scale. Identification of the receiving large marine ecosystems (LMEs) included

The distribution of $\mathrm{FF}_{\mathrm{Nmar}}$ reflects the longer persistence in receiving marine systems like the Bay of Bengal, the Baltic, Mediterranean, and Black Seas, and the Hudson Bay Complex (Table S.1). This pattern is altered by the influence of the riverine removal, represented by the $\mathrm{FF}_{\mathrm{Nriv}}$. Here, the river basin area and length are determinant to estimate the riverine denitrification losses (Dumont et al. 2005), the removals by retention in reservoirs (Seitzinger et al. 2002), and anthropogenic consumption (Mayorga et al. 2010). In practice, smaller river basins discharge higher DIN fractions. This is particularly visible in the majority of small river basins in the Arabian Peninsula,

Philippines/Indonesia Sea, and subarctic river basins of Alaska, North of Canada, and Russia (Fig. 1). Fate factors for soils emissions $\left(\mathrm{FF}_{\mathrm{Nsoil}}\right)$ (Fig. S.2) show the influence of predominant land use, based on modelling work by Bouwman et al. $(2005,2009)$ on explicit source and sink terms and agricultural surplus, respectively for natural and agricultural 
soils (Mayorga et al. 2010). These FFs for watershed diffuse emissions tend to show higher contributions from natural nitrogen fixation in large subarctic basins (e.g. Alaska, Canada, and Russia), from agricultural use of soils (manure and agricultural fixation) in South America and Western Africa, and fertilizer use in South and Southeast Asia and Oceania, matching the contribution analysis in riverine discharges by Lee et al. (2016).

Fate factors are not available for endorheic basins (as no export to marine waters occurs), for emissions from soils in arid areas (as evaporation exceeds precipitation on an annual basis, runoff is null and so are FE $\mathrm{ws}_{\mathrm{ws}, \mathrm{DIN}}$ coefficients), and basins exporting to non-LME spatial units (mainly in East Indonesian Sea and New Guinea, for which no marine fate component is available).

\subsection{Spatial differentiation}

Spatial differentiation of the fate factors per emission route, at a river basin scale, is summarized in Table 2 . The analysis across all calculated FFs shows 5 orders of magnitude variation for diffuse $\mathrm{N}$ emissions from soils, 3 for point emissions to river, and 2 for point emissions to marine water. Mean FF values decrease from a maximum for direct emissions to marine water $\left(\mathrm{N}_{\text {mar }}\right)$ to lower values for river-related emissions and lowest for soil-related emissions. These observations reflect the increasing removal upstream and the effect of the higher spatial differentiation of the coefficients used in the river and soil sub-models, i.e. the emission point moves further away from the sea in the hydrological cycle and processes like riverine removal (tier 2) and watershed/soil removal (tier 3) become active.

Table 2 Statistics of the distribution of fate factors (FF, [yr]) results per emission route at a river basin scale

\begin{tabular}{lrrr}
\hline Statistics & \multicolumn{3}{c}{ Fate Factor [yr] per emission route } \\
\cline { 2 - 4 } & $\mathrm{N}_{\text {soil }}$ & $\mathrm{N}_{\text {riv }}$ & $\mathrm{N}_{\text {mar }}$ \\
\hline Minimum & $2.1 \mathrm{E}-06$ & $2.7 \mathrm{E}-04$ & 0.03 \\
$5^{\text {th }}$ percentile & $2.0 \mathrm{E}-03$ & 0.04 & 0.09 \\
Mean & 0.09 & 0.39 & 0.74 \\
95 & 0.32 & 1.0 & 1.8 \\
Maximum & 1.1 & 1.7 & 2.8 \\
Spatial variability & $5 \mathrm{E}+05$ & $6 \mathrm{E}+03$ & $1 \mathrm{E}+02$ \\
\hline
\end{tabular}

Regionally aggregated fate factors at the level of continents (Table 3) show higher values for South Asia, followed by Europe for $\mathrm{N}_{\text {soil }}$, Europe and South Asia for $\mathrm{N}_{\text {riv }}$, and South Asia and Europe for $\mathrm{N}_{\text {mar }}$, reflecting predominant land uses, as noted by Lee et al. (2016). Regional FFs at the level of continents show modest variability, i.e. less than 1 order of magnitude in the inter-regional comparison, with no relevant distinction between emission routes. The variability of the FFs in each region (intra-regional comparison) shows higher differentiation in North and South America, again higher for the soil-related emissions, with ca. 4 orders of magnitude. The global aggregation 
(World, i.e. a site-generic factor) shows about 7-fold increase from soil-related emissions to direct coastal emissions, in a pattern that follows the emission pathway (soil-river-coast). Overall, regional aggregation decreases the spatial differentiation from a maximum at the disaggregated FFs (river basin scale), by roughly 4 orders of magnitude for soilrelated, 3 for river-related, and $\approx 1$ for direct coastal emissions. This analysis suggests a recommended use of the river basin scale for application of the proposed FFs, whenever emission location information is available. Aggregated FFs can be applied if such information is coarse, and the global average FFs when the location is unknown or spatial information is not relevant.

Table 3 Regional fate factors (FF, [yr]) by emission-weighted aggregation per emissions route at the level of continents. Intraregional variability (var) and inter-regional variability $\left(\mathrm{N}_{i}\right)$ shown

\begin{tabular}{lccr}
\hline Aggregation scale & \multicolumn{3}{c}{ Fate Factor [yr] per emission route } \\
\cline { 2 - 4 } & $\mathrm{N}_{\text {soil }}$ var & $\mathrm{N}_{\text {riv }}$ var & \multicolumn{1}{c}{$\mathrm{N}_{\text {mar }}$ var } \\
\hline Africa & $0.021 E+04$ & $0.136 E+02$ & $0.692 E+01$ \\
Europe & $0.133 E+02$ & $0.426 E+01$ & $1.12 E+01$ \\
North America & $0.037 E+04$ & $0.092 E+03$ & $0.262 E+01$ \\
South America & $0.017 E+04$ & $0.077 E+02$ & $0.221 E+01$ \\
North Asia & $0.057 E+01$ & $0.319 E+00$ & $0.895 E+00$ \\
South Asia & $0.176 E+03$ & $0.342 E+02$ & $1.35 E+01$ \\
Oceania ${ }^{a}$ & $0.051 E+03$ & $0.282 E+01$ & $0.631 E+01$ \\
Australia & $0.024 E+02$ & $0.087 E+00$ & $0.191 E+00$ \\
Spatial variability & $1 E+01--$ & $6 E+00--$ & $7 E+00--$ \\
\hline World & $0.12--$ & $0.25--$ & $0.87--$ \\
${ }^{a}$ (excluding Australia) & & &
\end{tabular}

${ }^{a}$ (excluding Australia)

\subsection{Qualitative comparison with other models}

The present work contributes a method to estimate fate factors for waterborne $\mathrm{N}$ emissions in a spatially explicit resolution that can consistently be applied at the global scale. The DIN removal coefficients extracted from the NEWS 2-DIN model were applied to estimate the runoff to watersheds and riverine environmental fate at a river basin scale, and were then coupled with coastal fate processes to finally estimate FFs. These two components combined, i.e. inland and marine, to the knowledge of the authors, find no comparable model acting in these two distinct environmental compartments, at the same global coverage, and scoped at the removals alone rather than a time-bound riverine export. The NEWS 2-DIN is believed to be the best available model for the purpose of FFs estimation with the present method. Alternatively, for the inland fate modelling, a similar extraction of $\mathrm{N}$ removal coefficients from the IMAGE-GNM model (Beusen et al. 2015) can be an option, although this would involve modelling additional spatial units and their aggregation - NEWS 2 is modelled at river basin scale, whereas IMAGE-GNM runs at a $0.5^{\circ} \times 0.5^{\circ}$ grid cell spatial resolution. River basins seem to be appropriate working units, where the variability of the occurring processes does not 
compromise the manageability and relevance of the results, hence its application here despite a single export fraction being assigned to each watershed area. However, IMAGE-GNM shows predictive advantages by adding detailed modelling of land fate processes, which includes explicit groundwater denitrification in the soil/aquifer matrix and riparian zones, instead of regression models that lump processes’ behaviour within watersheds by means of export constants. NEWS 2 addresses the spatial variability of sources and sinks to a limited extent, and misses the non-linearity of the biogeochemical processes (Beusen et al. 2015), especially for N sinks, but sources are based on the same model work by Bouwman et al. $(2005,2009)$. In practice, upstream emissions modelled in a watershed scale always result in the same export fraction as downstream emissions. Although this distinction could be environmentally relevant, some attenuation may occur due to the tendency of higher population density in lower reaches of the watershed and higher agricultural activity in mid-river draining areas. Nevertheless, the average approach adopted seems sufficient for the purpose, under a parsimony principle and considering the significant spatial differentiation of the FFs. Moreover, spatial information of life cycle inventories tends to show coarse hydrological resolution, so the simple identification of the receiving watershed would be adequate.

The SPARROW model (Smith et al. 1997; Alexander et al. 2008) adopts a hybrid statistical and process-based approach to estimate riverine total $\mathrm{N}$ yields in a U.S. river basin network (not compatible with the network used here) and does not include water consumption as a removal process. Similarly, TRACI (Bare et al. 2003) is scoped to U.S. states, $\mathrm{NH}_{3}$ is not covered, and no explicit $\mathrm{N}$ removal processes are modelled. CARMEN (Klepper et al. 1995) was developed for European applications and removal processes do not cover riverine retention or water consumption. Other site-specific and mechanistic models are available (reviewed by Borah and Bera 2003), but require extensive parameterisation and datasets, which are not consistent with a globally wide application. Comparison of the inland fate component to these models is therefore not possible.

The marine fate component is based on surface water residence time data to estimate removal rates by advection and denitrification and proxy the persistence of the newly added DIN fraction in coastal waters. As such, no comparable approaches were found available, as most are steady-state box models (often multidimensional) aiming at rivers or estuaries residence time estimations (Lucas 2016). Specifically for the removal rates by advective transport, the model approach by Laruelle et al. (2013) presents coastal water residence times with global coverage. However, these correspond to the entire water column, thus not consistent with the present purpose, in which the focus is on water persistence in the euphotic zone for $\mathrm{N}$ uptake by phytoplankton. Literature review was therefore preferred, providing residence times for 39 of 66 LMEs, whereas archetypical conditions were defined for the remaining 27. Regarding the 
removal rates by denitrification, Seitzinger et al. (2006) extended work by Nixon et al. (1996) in the attempt to relate denitrification losses and residence time. No further approaches at such wide coverage or specific to the desired scope of marine coastal waters were identified.

Given the fact that riverine export of dissolved inorganic phosphorus (DIP) may also contribute to nutrient enrichment of coastal waters and that $\mathrm{P}$ may also be the limiting nutrient in receiving marine waters, FFs for DIP emissions may be derived in a similar model framework too. This can be done by adopting the DIP export coefficients from the NEWS 2-DIP sub-model. The availability of both DIN and DIP FFs would be useful for LCIA models when P limitation in receiving marine water masses has been verified, or when co-limitation or variable temporal limitation may occur.

The identification of the limiting nutrient in LMEs, or any receiving coastal waters, should be based on scientific results to go beyond the simplification done here by assuming nitrogen as the limiting nutrient in marine waters. Local expert judgement may also be relevant. Although based on distinct modelling fundaments and aims, the ICEP approach (Garnier et al. 2010) may be useful as an indicator of the limiting nutrient in riverine discharges and e.g. help define the limiting nutrient on coastal waters and the most appropriate FF to be applied, once FFs for phosphorus forms are developed.

\subsection{Sensitivity and uncertainties}

The model sensitivity to the three input parameters, i.e. the inland fate export coefficients $\left(\mathrm{FE}_{\mathrm{ws}, \mathrm{DIN}}, \mathrm{FE}_{\mathrm{riv}, \mathrm{DIN}}\right)$ and the marine residence time $\left(\tau_{\mathrm{LME}}\right)$ in the marine fate component, was assessed by means of sensitivity ratios $(\mathrm{SR})$ calculated as the ratio between the relative change in the model output and the relative change in the input parameters. Neutral sensitivity $(\mathrm{SR}=1.00)$ to the two inland coefficients and an average $\mathrm{SR}=0.64$ for $\tau_{\mathrm{LME}}$ were obtained. Sensitivity to $\tau_{\mathrm{LME}}$ (SR $\mathrm{LME}_{\mathrm{Larying}}$ between $\left.0.49-0.95\right)$ were also found inversely correlated $(r=-0.47)$ to $\tau_{\mathrm{LME}}$.

It is beyond the present scope to discuss the uncertainty of the underlying models that compose the NEWS 2 models suite, namely soil budget, runoff, sewage water treatment efficiency, riverine retention and denitrification, river basin network, and others. However, as the NEWS 2-DIN was adopted, its validation is a relevant issue. NEWS 2-DIN calibration against observed DIN yields at the mouths of 66 large river basins (range $28-5847 \times 10^{3} \mathrm{~km}^{2}$ ) across the world shows reasonable robustness (explained variance $R^{2}=0.54$ ) in predicted vs. observed DIN yields, with an absolute model error of 6\% (Mayorga et al. 2010). As the present inland fate component does not include the watershed and river sources (quantified emissions) described in Mayorga et al. (2010), and their inherent uncertainty, the overall model error is likely to be lower for the removal coefficients alone. 
The literature review of residence time data revealed high inconsistency of sources. Such variability led to the adoption of best estimates, averaged source data, or checks for both consistency with adjacent areas and expected archetypical conditions. Therefore, the archetype-based residence times defined for $41 \%$ of the LMEs may hold a reasonable amount of (unquantified) uncertainty, although their $\mathrm{FF}_{\mathrm{Nmar}}$ values match those of adjacent LMEs. Expert judgement was applied to estimate probable shelf conditions based on bathymetric maps and the archetype-based residence time values were positively checked against online bathymetry sources, e.g. General Bathymetric Chart of the Oceans (GEBCO), European Marine Observation and Data Network (EMODnet), or NOAA's National Ocean Service (NOS) Office of Coast Survey. Nevertheless, the inconsistency or scarcity of studies is the major source of uncertainty in the residence time dataset. Further research on water residence time at a LME scale is suggested to improve the quality of the dataset, given that this parameter is used to estimate the marine component of the FFs.

The regression method adopted to estimate $\mathrm{N}$ removal by denitrification as a function of water residence time has $R^{2}=0.56$ while using several data points from freshwater systems and estuaries (Seitzinger et al. 2006). Although this fact seems not to influence the denitrification rates, a regression based on marine residence time data properly integrated for LME area and euphotic depth (as N uptake only occurs in this upper layer) would improve the confidence in the denitrification rates, and at the same time the quality and consistency of the advective DIN transport term.

The emission-weighted averaging method applied to the regional aggregation of FFs is bound to the quality of the DIN emissions data. The regional aggregation presented here is based on data for year 2000 and therefore may misrepresent any other given year of interest. An appropriate update of the regional FFs should be considered, if relevant for their application, or temporal inconsistency noted; interannual variability in DIN emissions and retention can be substantial at regional or basin scales (Beusen et al. 2016) and long-term trends at continental to global scales are also important (Seitzinger et al. 2010; Beusen et al. 2016); but the uncertainty of these numbers is likely to be of minor importance when averaging up to the level of continents.

The quality of the adopted removal coefficients is bound to the performance and calibration of the NEWS 2DIN. The Global NEWS models suite is built on various datasets and the results aim at being representative of year 2000. Changes in the removal coefficients resulting from potential alterations, caused by e.g. climate change or human interventions, in the driving parameters of that scenario, like water runoff, nutrients soil budgets, land use, and others (Seitzinger et al. 2005; Mayorga et al. 2010) are necessarily not reflected. A recalibration of the NEWS 2-DIN model could minimise the uncertainty introduced by those potential alterations and improve the confidence on that model and the results of the method proposed here. 


\section{Conclusions and outlook}

Fate factors representing the persistence of riverine exports of waterborne nitrogen emissions in coastal marine waters were developed with global coverage at a river basin scale. These fate factors account for spatial differences pertaining to three emission sources, i.e. DIN runoff from soils, and direct DIN emissions to either surface fresh- or marine waters. The Global NEWS 2-DIN model coefficients were applied to estimate the riverine fractions exported. Marine surface water residence time was then used to estimate the persistence in this compartment. A total of 17316 fate factors were calculated covering 5772 river basins in the world. Up to five orders of magnitude of variation was observed for DIN emissions from soils, dropping to a maximum of one order of magnitude variation when the fate factors were aggregated to the level of continents. Fate factors with spatial resolution at river basin scale are recommended over regionally aggregated, provided that emission location is available. The proposed method and its spatially explicit results enable a significant increase in geographic coverage for application in LCIA. For completeness of the coverage of $\mathrm{N}$ emissions, future work is directed to the derivation of similar FFs for dissolved organic nitrogen and particulate nitrogen forms. As phosphorus may also contribute to coastal nutrient enrichment and be a limiting nutrient there, the derivation of FFs applicable to emissions of phosphorus forms may also be included in future developments. For both cases mentioned, the relevant and necessary coefficients are embedded in the NEWS 2 suite of models.

Airborne emissions of nitrogen forms such as $\mathrm{NO}_{x}$ and $\mathrm{NH}_{3}$ undoubtedly constitute a relevant component of the environmental $\mathrm{N}$ cycling and also a significant flow from human activities. Energy production and agricultural activity are the most significant sources of emission of these compounds, which are further affected by atmospheric dispersion and deposition (Socolow 1999; Galloway et al. 2002). The inclusion of such emissions seems an essential step forward in the fate modelling of anthropogenic $\mathrm{N}$ emissions. Deposition fractions of any of these compounds, as done by e.g. Dentener et al. (2006) or Roy et al. (2012), can be coupled to the waterborne FFs described here to ensure that also airborne emissions can be covered in the modelling of marine eutrophication. This constitutes an area of future research.

\section{Acknowledgements}

The present research was partially funded by the European Commission under the 7th Framework Programme on Environment, ENV.2009.3.3.2.1: LC-IMPACT_-Improved Life Cycle Impact Assessment methods (LCIA) for better sustainability assessment of technologies, grant agreement number 243827 


\section{References}

Alexander RB, Smith RA, Schwarz GE, et al (2008) Differences in Phosphorus and Nitrogen Delivery to the Gulf of Mexico from the Mississippi River Basin. Environ Sci Technol 42:11-12.

Andrews JC, Müller H (1983) Space-time variability of nutrients in a lagoonal patch reef. Limnol Oceanogr 28:215227. doi: 10.4319/lo.1983.28.2.0215

Arrigo KR (2005) Marine microorganisms and global nutrient cycles. Nature 437:349-356. doi: 10.1038/nature04159

Bare JC, Norris GA, Pennington DW (2003) The Tool for the Reduction and Assessment Impacts. J Ind Ecol 6:49-78. doi: $10.1162 / 108819802766269539$

Beusen AHW (2005) User manual of CARMEN1. (not published). Bilthoven, the Netherlands

Beusen AHW, Bouwman AF, Van Beek LPH, et al (2016) Global riverine N and P transport to ocean increased during the 20th century despite increased retention along the aquatic continuum. Biogeosciences 113:2441-2451. doi: 10.5194/bgd-12-20123-2015

Beusen AHW, Dekkers, Bouwman AF, et al (2005) Estimation of global river transport of sediments and associated particulate C, N, and P. Global Biogeochem Cycles 19:1-17. doi: 10.1029/2005GB002453

Beusen AHW, Van Beek LPH, Bouwman AF, et al (2015) Coupling global models for hydrology and nutrient loading to simulate nitrogen and phosphorus retention in surface water - description of IMAGE-GNM and analysis of performance. Geosci Model Dev 8:4045-4067. doi: 10.5194/gmd-8-4045-2015

Borah DK, Bera M (2003) Watershed-scale hydrologic and nonpoint-source pollution models: Review of mathematical bases. Trans Am Soc Agric Eng 46:1553-1566.

Bouwman AF, Beusen AHW, Billen G (2009) Human alteration of the global nitrogen and phosphorus soil balances for the period 1970-2050. Global Biogeochem Cycles 23:1-16. doi: 10.1029/2009GB003576

Bouwman AF, Van Drecht G, Knoop JM, et al (2005) Exploring changes in river nitrogen export to the world's oceans. Global Biogeochem Cycles 19:14. doi: 10.1029/2004GB002314

Cloern JE (2001) Our evolving conceptual model of the coastal eutrophication problem. Mar Ecol Prog Ser 210:223253. doi: $10.3354 / \operatorname{meps} 210223$

Cosme N, Hauschild MZ (2016) Effect factors for marine eutrophication in LCIA based on species sensitivity to hypoxia. Ecol Indic 69:453-462. doi: 10.1016/j.ecolind.2016.04.006

Cosme N, Hauschild MZ (2017) Characterization of waterborne nitrogen emissions for marine eutrophication modelling in life cycle impact assessment at the damage level and global scale. Int J Life Cycle Assess 
22(10):1558-1570. doi: 10.1007/s11367-017-1271-5

Cosme N, Koski M, Hauschild MZ (2015) Exposure factors for marine eutrophication impacts assessment based on a mechanistic biological model. Ecol Modell 317:50-63. doi: 10.1016/j.ecolmodel.2015.09.005

Dentener FJ, Drevet J, Lamarque JF, et al (2006) Nitrogen and sulfur deposition on regional and global scales: A multimodel evaluation. Global Biogeochem Cycles 20:1-21. doi: 10.1029/2005GB002672

Dettmann EH (2001) Effect of Water Residence Time on Annual Export and Denitrification of Nitrogen in Estuaries: A Model Analysis. Estuaries 24:481-490.

Diaz RJ, Rosenberg R (1995) Marine Benthic Hypoxia: a Review of Its Ecological Effects and the Behavioural Responses of Benthic Macrofauna. In: Ansell AD, Gibson RN, Barnes M (eds) Oceanography and Marine Biology: an Annual Review. UCL Press, pp 245-303

Diaz RJ, Rosenberg R (2008) Spreading dead zones and consequences for marine ecosystems. Science (80- ) 321:926929. doi: $10.1126 /$ science. 1156401

Doney SC (2010) The Growing Human Footprint on Coastal and Open-Ocean Biogeochemistry. Science (80- ) 328:1512-1516. doi: $10.1126 /$ science. 1185198

Dumont E, Harrison JA, Kroeze C, et al (2005) Global distribution and sources of dissolved inorganic nitrogen export to the coastal zone: Results from a spatially explicit, global model. Global Biogeochem Cycles 19:GB4S02. doi: $10.1029 / 2005$ GB002488

Elser JJ, Bracken MES, Cleland EE, et al (2007) Global analysis of nitrogen and phosphorus limitation of primary producers in freshwater, marine and terrestrial ecosystems. Ecol Lett 10:1135-42. doi: 10.1111/j.14610248.2007.01113.x

Fear J, Thompson S, Gallo T, Paerl H (2005) Denitrification rates measured along a salinity gradient in the eutrophic Neuse River estuary, North Carolina, USA. Estuaries and Coasts 28:608-619. doi: 10.1007/BF02696071

Fekete BM, Vörösmarty CJ, Grabs W (2000) Global Composite Runoff Fields on Observed River Discharge and Simulated Water Balances. Koblenz, Germany

Galloway JN, Cowling EB (2002) Reactive nitrogen and the world: 200 years of change. Ambio 31:64-71. doi: $10.2307 / 4315217$

Galloway JN, Cowling EB, Seitzinger SP, Socolow RH (2002) Reactive nitrogen: too much of a good thing? Ambio $31: 60-3$.

Galloway JN, Dentener FJ, Capone DG, et al (2004) Nitrogen cycles: past, present, and future. Biogeochemistry 
$70: 153-226$.

Galloway JN, Townsend AR, Erisman JW, et al (2008) Transformation of the Nitrogen Cycle: Recent Trends, Questions, and Potential Solutions. Science (80- ) 320:889-892. doi: 10.1126/science.1136674

Garnier J, Beusen AHW, Thieu V, et al (2010) N:P:Si nutrient export ratios and ecological consequences in coastal seas evaluated by the ICEP approach. Global Biogeochem Cycles 24:GB0A05. doi: 10.1029/2009GB003583

GESAMP (2001) A Sea of Troubles. Rep. Stud. GESAMP No. 70. Joint Group of Experts on the Scientific Aspects of Marine Environmental Protection and Advisory Committee on Protection of the Sea.

Goedkoop M, Heijungs R, Huijbregts MAJ, et al (2012) ReCiPe 2008 - A life cycle impact assessment method which comprises harmonised category indicators at the midpoint and the endpoint level. First edition (revised) Report I: Characterisation; July 2012, http://www.lcia-recipe.net

Gray JS, Wu RS, Or YY (2002) Effects of hypoxia and organic enrichment on the coastal marine environment. Mar Ecol Prog Ser 238:249-279.

Green PA, Vörösmarty CJ, Meybeck M, et al (2004) Pre-industrial and contemporary fluxes of nitrogen through rivers: a global assessment based on typology. Biogeochemistry 68:71-105.

Hauschild MZ, Goedkoop M, Guinée JB, et al (2013) Identifying best existing practice for characterization modeling in life cycle impact assessment. Int J Life Cycle Assess 18:683-697. doi: 10.1007/s11367-012-0489-5

Hauschild MZ, Potting J (2005) Spatial Differentiation in Life Cycle Impact Assessment - The EDIP2003 methodology. Henderson AD (2015) Eutrophication. In: Hauschild MZ, Huijbregts MAJ (eds) Life Cycle Impact Assessment, LCA Compendium - The Complete World of Life Cycle Assessment. Springer Science+Business Media Dordrecht, pp $177-196$

Howarth R, Chan F, Conley DJ, et al (2011) Coupled biogeochemical cycles: Eutrophication and hypoxia in temperate estuaries and coastal marine ecosystems. Front Ecol Environ 9:18-26. doi: 10.1890/100008

Howarth RW, Billen G, Swaney D, et al (1996) Regional nitrogen budgets and riverine N \& P fluxes for the drainages to the North Atlantic Ocean: Natural and human influences. Biogeochemistry 35:75-139. doi: 10.1007/BF02179825

Howarth RW, Marino R (2006) Nitrogen as the limiting nutrient for eutrophication in coastal marine ecosystems: Evolving views over three decades. Limnol Oceanogr 51:364-376. doi: 10.4319/lo.2006.51.1_part_2.0364 Huang J, Xu C, Ridoutt BG, et al (2017) Nitrogen and phosphorus losses and eutrophication potential associated with fertilizer application to cropland in China. J Clean Prod 159:171-179. doi: 10.1016/j.jclepro.2017.05.008 
Kelly JR (2008) Nitrogen Effects on Coastal Marine Ecosystems. In: Hatfield JL, Follet RF (eds) Nitrogen in the Environment: Sources, Problems, and Management. Academic Press, Elsevier, Amsterdam, Boston, et al., pp $271-332$

Klepper O, Beusen AHW, Meinardi CR (1995) Modelling the flow of nitrogen and phosphorus in Europe: From loads to coastal seas. Bilthoven, the Netherlands

Kroeze C, Bouwman AF, Seitzinger SP (2012) Modeling global nutrient export from watersheds. Curr Opin Environ Sustain 4:195-202. doi: 10.1016/j.cosust.2012.01.009

Laruelle GG, Dürr HH, Lauerwald R, et al (2013) Global multi-scale segmentation of continental and coastal waters from the watersheds to the continental margins. Hydrol Earth Syst Sci 17:2029-2051. doi: 10.5194/hess-17-20292013

Lee RY, Seitzinger SP, Mayorga E (2016) Land-based nutrient loading to LMEs: A global watershed perspective on magnitudes and sources. Environ Dev. doi: 10.1016/j.envdev.2015.09.006

Levin LA, Ekau W, Gooday AJ, et al (2009) Effects of natural and human-induced hypoxia on coastal benthos. Biogeosciences 6:2063-2098.

Lucas L V (2016) Encyclopedia of Estuaries. In: Kennish MJ (ed). Springer Netherlands, Dordrecht, pp 502-503 Magalhães CM, Joye SB, Moreira RM, et al (2005) Effect of salinity and inorganic nitrogen concentrations on nitrification and denitrification rates in intertidal sediments and rocky biofilms of the Douro River estuary, Portugal. Water Res 39:1783-1794. doi: 10.1016/j.watres.2005.03.008

Mayorga E, Seitzinger SP, Harrison JA, et al (2010) Global Nutrient Export from WaterSheds 2 (NEWS 2): Model development and implementation. Environ Model Softw 25:837-853. doi: 10.1016/j.envsoft.2010.01.007

Middelburg JJ, Levin LA (2009) Coastal hypoxia and sediment biogeochemistry. Biogeosciences 6:1273-1293. doi: $10.5194 /$ bg-6-1273-2009

Monsen NE, Cloern JE, Lucas L V., Monismith SG (2002) The use of flushing time, residence time, and age as transport time scales. Limnol Oceanogr 47:1545-1553. doi: 10.4319/lo.2002.47.5.1545

Nixon SW (1995) Coastal marine eutrophication: A definition, social causes, and future concerns. Ophelia 41:199-219.

Nixon SW, Ammerman JW, Atkinson LP, et al (1996) The fate of nitrogen and phosphorus at the land-sea margin of the North Atlantic Ocean. Biogeochemistry 35:141-180.

NRC (2000) Clean Coastal Waters: Understanding and Reducing the Effects of Nutrient Pollution. National Academy Press, Washington, DC 
Pennington DW, Potting J, Finnveden G, et al (2004) Life cycle assessment Part 2: Current impact assessment practice. Environ Int 30:721-39. doi: 10.1016/j.envint.2003.12.009

Potting J, Hauschild MZ (2006) Spatial Differentiation in Life Cycle Impact Assessment: A decade of method development to increase the environmental realism of LCIA. Int J Life Cycle Assess 11:11-13.

Rabalais NN (2002) Nitrogen in Aquatic Ecosystems. Ambio 31:102-112.

Rabalais NN, Diaz RJ, Levin LA, et al (2010) Dynamics and distribution of natural and human-caused coastal hypoxia. Biogeosciences 7:585-619. doi: 10.5194/bgd-6-9359-2009

Roy P-O, Huijbregts MAJ, Deschênes L, Margni M (2012) Spatially-differentiated atmospheric source-receptor relationships for nitrogen oxides, sulfur oxides and ammonia emissions at the global scale for life cycle impact assessment. Atmos Environ 62:74-81. doi: 10.1016/j.atmosenv.2012.07.069

Seitzinger SP (1988) Denitrification in freshwater and coastal marine ecosystems: Ecological and geochemical significance. Limnol Oceanogr 33:702-724. doi: 10.4319/1o.1988.33.4_part_2.0702

Seitzinger SP, Harrison JA, Böhlke JK, et al (2006) Denitrification across landscapes and waterscapes: A synthesis. Ecol Appl 16:2064-2090.

Seitzinger SP, Harrison JA, Dumont E, et al (2005) Sources and delivery of carbon, nitrogen, and phosphorus to the coastal zone: An overview of Global Nutrient Export from Watersheds (NEWS) models and their application. Global Biogeochem Cycles 19:1-11. doi: 10.1029/2005GB002606

Seitzinger SP, Kroeze C, Bouwman AF, et al (2002) Global patterns of dissolved inorganic and particulate nitrogen inputs to coastal systems: Recent conditions and future projections. Estuaries 25:640-655. doi:

\subsection{7/BF02804897}

Seitzinger SP, Mayorga E, Bouwman AF, et al (2010) Global river nutrient export: A scenario analysis of past and future trends. Global Biogeochem Cycles 24:GB0A08. doi: 10.1029/2009GB003587

Sherman K, Alexander LM (eds) (1986) Variability and Management of Large Marine Ecosystems. Westview Press Inc., Boulder, $\mathrm{CO}$

Smith RA, Schwarz GE, Alexander RB (1997) Regional interpretation of water-quality monitoring data. Water Resour Res 33:2781. doi: 10.1029/97WR02171

Smith VH, Joye SB, Howarth RW (2006) Eutrophication of freshwater and marine ecosystems. Limnol Oceanogr $51: 351-355$

Smith VH, Tilman GD, Nekola JC (1999) Eutrophication: impacts of excess nutrient inputs on freshwater, marine, and 
terrestrial ecosystems. Environ Pollut 100:179-196.

Socolow RH (1999) Nitrogen management and the future of food: Lessons from the management of energy and carbon. Proc Natl Acad Sci U S A 96:6001-6008.

Strokal M, Kroeze C, Wang M, et al (2016) The MARINA model (Model to Assess River Inputs of Nutrients to seAs): Model description and results for China. Sci Total Environ 562:869-888. doi: 10.1016/j.scitotenv.2016.04.071

Toffoletto L, Bulle C, Godin J, et al (2007) LCA Methodology LUCAS - A New LCIA Method Used for a CAnadianSpecific Context. Int J Life Cycle Assess 12:93-102.

Turner RE, Qureshi N, Rabalais NN, et al (1998) Fluctuating silicate: nitrate ratios and coastal plankton food webs. Proc Natl Acad Sci U S A 95:13048-13051.

Udo de Haes HA, Finnveden G, Goedkoop M, et al (2002) Life-Cycle Impact Assessment: Striving Towards Best Practice. SETAC Press, Pensacola, FL, USA

Van Drecht G, Bouwman AF, Harrison JA, Knoop JM (2009) Global nitrogen and phosphate in urban wastewater for the period 1970 to 2050. Global Biogeochem Cycles 23:1-19. doi: 10.1029/2009GB003458

Van Drecht G, Bouwman AF, Knoop JM, et al (2003) Global modeling of the fate of nitrogen from point and nonpoint sources in soils, groundwater, and surface water. Global Biogeochem Cycles 17:1-20. doi:

$10.1029 / 2003$ GB002060

Van Jaarsveld JA (1995) Modelling the long-term atmospheric behaviour of pollutants on various spatial scales. PhD Thesis. University of Utrecht

Vitousek PM, Hättenschwiler S, Olander L, Allison S (2002) Nitrogen and nature. Ambio 31:97-101.

Vollenweider RA (1976) Advances in defining critical loading levels for phosphorus in lake eutrophication. Mem dell'Istituto Ital di Idrobiol dott Marco Marchi 33:53-83.

Vörösmarty CJ, Fekete BM, Meybeck M, Lammers RB (2000a) Geomorphic attributes of the global system of river at 30-minute spatial resolution. J Hydrol 237:17-39.

Vörösmarty CJ, Fekete BM, Meybeck M, Lammers RB (2000b) Global system of rivers: its role in organizing continental land mass and defining land-to-ocean linkages. Global Biogeochem Cycles 14:599-621. doi: 10.1029/1999GB900092

Wu RS (2002) Hypoxia: from molecular responses to ecosystem responses. Mar Pollut Bull 45:35-45.

Zhang J, Gilbert D, Gooday AJ, et al (2010) Natural and human-induced hypoxia and consequences for coastal areas: synthesis and future development. Biogeosciences 7:1443-1467. doi: 10.5194/bg-7-1443-2010 